\title{
THE IMPORTANT SELECTION CRITERIA IN CHOOSING ISLAMIC BANKS: A SURVEY IN BAHRAIN
}

\author{
Abdulla Hamzah Al-Hadrami ${ }^{1}$, Sutan Emir Hidayat ${ }^{2}$, Mohamed Isa Al-Sharbiti ${ }^{3}$
}

\begin{abstract}
The Important Selection Criteria in Choosing Islamic Banks: A Survey in Babrain. Selection criteria of banks in general and Islamic banks in particular have been given high attention by the marketing researchers nowadays. But this kind of research is still insufficient in numbers especially in the developing countries. Therefore, this study aims to identify the important selection criteria that are considered by customers in selecting Islamic banks in the Kingdom of Bahrain. A 5-Likert scale survey questionnaire and ANOVA were used as the research method. The results indicate that the religious factors were ranked as the most important selection criteria for selecting Islamic banks. The study also found service quality factors as the second important selection criteria. This study is expected to provide Islamic banks in Bahrain with some inputs in setting up their marketing strategies in order to attract new customers and retain their existing customers. This study is also expected to add value to the literature by providing the updated empirical study in the area.
\end{abstract}

Keywords: selection criteria, customers, Islamic banks

\begin{abstract}
Abstrak. Kriteria Pemilihan Utama dalam Menentukan Bank Syariab: Survei di Babrain. Kriteria pemilihan bank secara umum maupun bank syariah secara khusus telah banyak dilakukan oleh para penelitian di bidang pemasaran saat ii. Akan tetapi, penelitian ini belum banyak dilakukan di negara berkembang. Penelitian ini bertujuan untuk mengidentifikasi kriteria pemilihan utama yang dipertimbangkan oleh nasabah dalam memilih bank syariah di Bahrain. Metode yang dipergunakan ialah kuesioner dengan skala likert dan ANOVA. Hasil menunjukkan bahwa faktor agama merupakan kriteria pemilihan utama dalam memilih bank syariah. Selain itu, penelitian ini juga menemukan bahwa faktor kualitas layanan menjadi kriteria pemilihan utama kedua. Penelitian ini diharapkan mampu memberikan kontribusi bagi bank syariah di Bahrain dalam menetapkan strategi pemasaran dalam kaitannya menarik nasabah baru dan mempertahankan nasabah lama. Selain itu diharapkan pula penelitian ini mampu memberikan pembaharuan literature terkait studi sejenis.
\end{abstract}

Kata kunci: kriteria pemilihan, nasabah, bank syariah 


\section{Introduction}

Despite Islam requires its followers to comply all aspects of their life including the financial matters with sharia, Islamic banking and finance was still unknown and unheard before 1970s. The momentum that led to the current development took place when the historical conference for the rulers in the Islamic world held on 25th September 1969 in Rabat, Kingdom of Morocco. The rulers have made the decision to establish the Organization of Islamic Conference (OIC), whose purpose was to unite the Muslim voice across the world and safeguard the concerns of the Muslim world in the spirit of promoting international peace and harmony among various people of the world (Mullineux \& Murinde, 2003). One of the results of the establishment of the OIC was the establishment of Islamic Development Bank (IDB).

Since that, Islamic Banks continued to grow and expand in size and in numbers. Currently, there are more than three hundreds Islamic financial institutions in over fifty-one countries with the total assets in 2013 had reached USD 1.3 Trillion (Izhar and Rehman, 2014). This gives an indication that this industry is growing quickly and sharply. The growth of this business is tremendous in comparison to other aspects of the financial industry (Ali, 2011).

One of the important countries to the development of Islamic banking and finance is Kingdom of Bahrain. Bahrain is known as the financial center of the Middle East. The financial service sector is among the highest contributors to the country's overall GDP. The sector represents around 27\% of GDP of the country. In addition, the financial service is the largest sector that absorbs the workforce in Bahrain. Up to September 2014, the number of financial institutions in the country is 404 and the total workforce is $14,009^{1}$.

Up to December 2014, there are 6 Islamic retail banks and 18 Islamic wholesale banks operating in the kingdom. The high numbers of Islamic banks shows high profile of the country as one of the worlds' leading Islamic financial centers. The importance of Islamic banking can be further substantiated with the increasing contribution of Islamic banking assets to the total banking system. The growth of Islamic banking in particular has been remarkable during 2000-2008, with total assets in this segment jumping from USD 1.9 billion in 2000 to USD 27.12 billion at the end of 2008, an increase of over 500\%. The market share of Islamic banks correspondingly increased from $1.8 \%$ of total banking assets in 2000 to around $13.3 \%$ in $2012^{2}$. As the Islamic banking grows in the Kingdom, Islamic banks need to recognize and realize the selection criteria that influence customers'

\footnotetext{
${ }^{1}$ http://www.cbb.gov.bh/page-p-overview1.htm. It was accessed on 17/12/2014.
}

${ }^{2}$ http://www.cbb.gov.bh/page-p-overview1.htm. It was accessed on 17/12/2014 
selection of Islamic banks. Understanding the selection criteria will enable them to increase their number of customers and thus the financial transactions performed. This will positively affect the banks' profitability.

Based on the above background, this study aims to identify the important selection criteria that are considered by customers in selecting Islamic banks in the Kingdom of Bahrain. In other words, this study aims to answer the following research questions: First, what are the important selections criteria considered by the customers in the process of selecting Islamic banks? Second, Do demographic variables significantly influence the selection criteria of Islamic banks?

This study is expected to provide Islamic banks in Bahrain with some inputs in setting up their marketing strategies in order to attract new customers and retain their existing customers. This study is also expected to add value to the literature by providing the updated empirical study in the area. The current study extends and complements the study of Metawa and Al-Mossawi (1998) by investigating the importance of other selection criteria which are not examined in that study, namely service quality and other convenience factors including comfort interior, the availability of parking space, the availability of wide range of branches and ATMs, and external appearance. Moreover, the current study tested the influence of gender on the selection criteria variables that have not been tested by Metawa and AlMossawi study. This demographic variable is considered an important factor that affects the customer's Bank selection.

Some findings of the current study are consistent with the findings of the previous studies and some findings are contrary to the findings of previous studies. Understanding the selection criteria which reflect the perceptions of the Islamic banks' customers is important for Islamic banks' stakeholders because these selection criteria determine how and to what extent customers choose to patronize the alternative products and services of the banks (Gait and Worthington, 2007).

\section{Literature Review}

There are quite significant numbers of studies that surveyed the selection criteria of customers towards Islamic banking services from time to time especially across countries where Islamic banks are currently operating. For example, Metawa and Al-Mossawi (1998) investigated the bank selection criteria for Islamic bank customers in Bahrain. The study collected questionnaire data from about 300 customers from two Islamic banks. The study found that religion was the primary selection criteria, followed by rate of return, recommendations made by family and friends and convenience. 
Dusuki and Abdullah (2006), investigated why customers patronize Islamic banks in Malaysia. The study was based on a sample of 750 respondents. The study found that the most important selection criteria in accepting Islamic banks are service quality, friendly staff, bank reputation, and Islamic working environment. Khan et al. (2007) conducted a study to investigate banks' selection criteria in Islamic banks in Bangladesh, based on a sample of 100 customers of Islamic banks who completed a questionnaire, and found that the most important selection criteria among Islamic banks' customers is the religious principles. Ranjbar and Sharif (2008) investigated on Islamic banking selection criteria in Malaysia, using data from 150 questionnaires completed by Muslim and non-Muslim customers. The study results indicated that there is no significant difference in the selection criteria between Muslim and non-Muslim customers. The key factors in selecting financial institutions were the provision of fast and efficient service, confidentiality of banks, bank reputation and image, provision of a wide range of services, lower profit rates on financings and the friendliness of bank personnel. Hague et al. (2009) investigated the major factors influencing the selection of Islamic banking in Malaysia, based on data collected from 485 customers through questionnaires. The study found that the factors influencing Islamic banking customers are quality of services, availability of services, social and religious perspectives and customers' confidence in the bank.

Bhatti et al. (2010) surveyed 120 customers in Pakistan. The study's results indicate that the main selection criteria of an Islamic bank are religiosity and profitability, efficiency and speed in completing transactions, and staff friendliness. Farooq et.al. (2010) studied the selection criteria of Islamic customers patronizing a particular bank in Afghanistan. The sample was based on 100 questionnaires. The study found that the most important factors leading to the customer's choice of Islamic banking products/services are religious reliance, recommendation of family and friends, easy access to branch, and profitability of the bank.

Abduh and Omar (2012) studied the rank of selected criteria of Islamic banking in Malaysia, collecting data by surveying 279 respondents from bank depositors through a survey and conducting data analysis using a quantitative approach. The study showed that the highest priority factors in choosing to patronize an Islamic bank are sharia compliance, profitability, bank reputation, bank status, facilities and services, and friendly personnel respectively. A recent study conducted by Hidayat and Al-Bawardi (2012) to evaluate the perceptions of non-Muslim expatriates in Saudi Arabia toward Islamic banking products and services collected questionnaire data from 103 non-Muslim expatriate bank customers for quantitative analysis. The study found that lower costs, better quality and nature of products and services provided motivated non-Muslim customers in Saudi Arabia to deal with the Islamic banking. 
In general, review of literature reveals that religious factors, quality of services performed by the Islamic banks, convenience, family and friends' influence, and financial benefit play major roles in the selection process and become the main selection criteria of Islamic banks. Using the above selection criteria, this study attempts to extend Metawa and Al-Mossawi (1998)'s study by conducting the updated survey in Bahrain in order to identify the important selection criteria that affect customers' selection of Islamic banks. In general, most of the previous studies including Metawa and Al-Mossawi (1998) did not test the differences among the respondents' opinion based on their demographic variables. Therefore, this study examined the significant differences in the respondents' opinion about the selection criteria of Islamic banks when the respondents are grouped according to gender, age, level of education, and level of income to fill the gap in the literature.

\section{Method}

Based on the above previous studies, it is found that most studies related to selection criteria of Islamic banking services used a 5-Likert scale survey questionnaire as their research method. A survey questionnaire is a kind of quantitative research approach. Therefore, this study uses the same method as the previous studies (Metawa and Al-Mossawi, 1998; Dusuki and Abdullah, 2006; Khan et al, 2007; Ranjbar and Sharif, 2008; Hague et al, 2009; Bhatti et.al, 2010; Farooq et al, 2010; Abduh and Omar, 2012; Hidayat and Al-Bawardi, 2012). The questionnaire used to collect the data for this study was developed based on the questionnaire of the above previous studies.

The items in the questionnaire are divided into 6 groups. The first group collects demographic profile of the respondents in terms of gender, age, level of education and level of income. The second group collects information about the respondents' opinion on the importance of religious factors as selection criteria of Islamic banks. There are 3 items under the category namely "You select Islamic bank because you want to follow Islam", "You select Islamic bank because you want to avoid Riba", and "You select Islamic bank because you want to comply with Shariah in all your dealings".

The third group collects information about the respondents' opinion on the importance of service quality factors as the selection criteria of Islamic banks. There are 3 items under this category namely "You select Islamic bank because of its fast and efficient service", "You select Islamic bank because of its accuracy in service transaction" and "You select Islamic bank because of its high quality of customer services". The fourth group collects information about the respondents' opinion on the importance of convenience in the selection of Islamic banks. In this category, 
there are 6 items namely "You select Islamic bank because of the bank' offices have comfort interior", "You select Islamic bank because of convenient branches location". "You select Islamic bank because of available parking space", "You select Islamic bank because of wide range of branches", "You select Islamic bank because of external appearance of the bank" and "You select Islamic bank because of wide ATM availability".

The fifth group collects information about the respondents' opinion on the importance of families and friends' influence as the selection criteria of Islamic banks. There are 3 items under this category namely "You select Islamic bank because of the recommendation from your family", "You select Islamic bank because of the recommendation from your friends" "You select Islamic bank because your families or friends are working for Islamic banks". The sixth group collects information about the respondents' opinion on the importance of financial benefits as the selection criteria of Islamic banks. There are 3 items under this category namely "You select Islamic bank because of the low profit rate on financings", "You select Islamic bank because of low service charges" and "You select Islamic bank because of high rate of return on deposits".

The population of this study consists of all customers of Islamic commercial banks in Bahrain. Convenience sampling was used since this technique is widely used for exploratory research, which involves samples drawn from part of population using a random approach. It simply gathers data from people who are readily available and accessible. 150 questionnaires were distributed to Islamic banks' customers. However, only 135 questionnaires were completely filled up and returned.

Analysis of Variance (ANOVA) test was applied to determine if there are any significant differences in the average weighted means obtained by the responses of the respondents when they are grouped according to the gender, age, level of education, and level of income. According to Hair et al. (2010) ANOVA is a technique used to determine whether two or more groups come from a population differ significantly or not in terms of a specific variable. The usage of ANOVA for the purpose of testing significant differences in the average weighted mean has been used by some previous studies with different objectives.(Hidayat and Al-Hadrami, 2015; Al-Hadrami and Hidayat, 2015.)

\section{Result and Discussions Demographic profiles}

From 135 Islamic bank customers participated in this survey, 73 of them $(54.1 \%)$ are male and 62 of them are female (45.9\%). In terms of age, 6 of them are below 25 years old (4.4\%), $43(31.9 \%)$ of them are in the range of $25-35$ years 
old. $33(24.4 \%)$ of them are in the range of $36-45$ years old. The remaining 53 respondents (39.3\%) are above 45 years old. In term of education, 1 respondent did not complete high school (0.7\%). 12 respondents $(8.9 \%)$ are high school graduates, 119 respondents $(88.1 \%)$ hold bachelor degree and 3 respondents $(2.2 \%)$ are holding postgraduate degrees. In term of income, 6 respondents (4.4\%) have monthly income below BD 450. 81 (60\%) respondents have monthly income in the range of BD 450900. 39 (28.9\%) respondents earn in the range of BD 901-1400 monthly and the remaining 9 respondents (6.6\%) earn above BD 1,400 monthly.

\section{Importance of religious factors as the selection criteria for Islamic banks}

Table 1 summarizes the respondents' responses regarding the importance of religious factors in the selection of Islamic banks. As seen in this Table the overall average of the respondents' responses regarding the religious factors is 4.02 , with a verbal interpretation of "Important". In addition, the average responses regarding the three elements of this category have a verbal interpretation of "Important". "Following Islam" has the highest average score (4.21), followed by "Avoiding riba", with an average score of 4.02 and "compliance with sharia", with an average score of 3.83. The findings indicate that religious factors viewed as important selection criteria of Islamic banks by Islamic bank customers in Bahrain.

Table 1. Summary of Respondents' Responses on the Importance of Religious Factors in the Selection of Islamic Banks ( $\mathrm{n}=135)$

\begin{tabular}{lccccccc}
\hline \multicolumn{1}{c}{ Item } & $\mathbf{1}$ & $\mathbf{2}$ & $\mathbf{3}$ & $\mathbf{4}$ & $\mathbf{5}$ & Mean & Interpretation \\
\hline $\begin{array}{l}\text { You select Islamic bank because you want } \\
\text { to follow Islam }\end{array}$ & 3 & 21 & 8 & 15 & 88 & 4.21 & Important \\
$\begin{array}{l}\text { You select Islamic bank because you want } \\
\text { to avoid Riba }\end{array}$ & 14 & 12 & 7 & 26 & 76 & 4.02 & Important \\
$\begin{array}{l}\text { You select Islamic bank because you want } \\
\text { to comply with Shariah in all your dealings }\end{array}$ & 12 & 17 & 7 & 45 & 54 & 3.83 & Important \\
\hline
\end{tabular}

Overall Weighted Average: 4.02 (Important)

The findings are in line with the findings of the previous studies (Metawa and Al-Mossawi, 1998; Khan et al, 2007; Hague et al, 2009; Bhatti et.al, 2010; Farooq et al, 2010; Abduh and Omar, 2012). This is also in line with the wisdom behind the establishment of Islamic banking and finance, which is to comply all aspects of our life as a Muslim into Shariah (Hidayat, 2010). 


\section{Importance of service quality factors as the selection criteria for Islamic banks}

Table 2 shows that the overall average of the respondents' responses regarding the service quality factors is 3.66, with a verbal interpretation of "Important". In addition, the average responses regarding the three elements of this category each has a verbal interpretation of "Important". "High quality of customer services" has the highest average score (3.73), followed by "fast and efficient service", with an average score of 3.69, and "accuracy in service transaction", with an average score of 3.57. The above findings indicate that service quality plays an important role in the selection process of Islamic banks (important selection criteria). Table 2 summarizes the respondents' responses regarding the importance of service quality factors in the selection of Islamic banks.

Table 2-Summary of Respondents' Responses on the Importance of Service Quality Factors in the Selection of Islamic Banks $(n=135)$

\begin{tabular}{lccccccc}
\hline \multicolumn{1}{c}{ Item } & $\mathbf{1}$ & $\mathbf{2}$ & $\mathbf{3}$ & $\mathbf{4}$ & $\mathbf{5}$ & Mean & Interpretation \\
\hline $\begin{array}{l}\text { You select Islamic bank because of fast } \\
\text { and efficient service }\end{array}$ & 3 & 12 & 41 & 47 & 32 & 3.69 & Important \\
$\begin{array}{l}\text { You select Islamic bank because of } \\
\text { accuracy in service transaction? }\end{array}$ & 1 & 6 & 59 & 53 & 16 & 3.57 & Important \\
$\begin{array}{l}\text { You select Islamic bank because of high } \\
\text { quality of customer services }\end{array}$ & 0 & 7 & 48 & 54 & 26 & 3.73 & Important \\
\hline
\end{tabular}

Overall Weighted Average: 3.66 (Important)

Therefore, Islamic banks management needs to pay attention to this aspect. The findings of this study confirm the findings of the previous studies (Dusuki and Abdullah, 2006; Ranjbar and Sharif, 2008; Hague et al, 2009; Bhatti et.al, 2010; Abduh and Omar, 2012; Hidayat and Al-Bawardi, 2012).

\section{Importance of convenience factors as the selection criteria for Islamic banks}

When it comes to the importance of convenience in the selection of Islamic banks, the weighted average results show that the overall average of the participants' responses regarding the convenience factors is 3.19, with a verbal interpretation of "Moderately important". Among the 6 items under this category, "Islamic bank's offices have a comfortable interior" has the highest average score (4.49), followed by "available parking space" with an average of 3.59 , both are categorized as "Important". 
Abdulla Hamzah Al-Hadrami: The Important Selection Criteria In Choosing Islamic Banks 173

Table 3-Summary of Respondents' Responses on the Importance of Convenience Factors

\begin{tabular}{lccccccc}
\hline \multicolumn{1}{c}{ Item } & $\mathbf{1}$ & $\mathbf{2}$ & $\mathbf{3}$ & $\mathbf{4}$ & $\mathbf{5}$ & Mean & Interpretation \\
\hline $\begin{array}{l}\text { You select Islamic banks because of the } \\
\text { banks' offices have comfort interior }\end{array}$ & 1 & 2 & 9 & 41 & 82 & 4.49 & Important \\
$\begin{array}{l}\text { You select Islamic banks because of } \\
\text { convenient branches location }\end{array}$ & 5 & 15 & 68 & 31 & 16 & 3.28 & $\begin{array}{l}\text { Moderately } \\
\text { Important }\end{array}$ \\
$\begin{array}{l}\text { You select Islamic banks because of } \\
\text { available parking space }\end{array}$ & 1 & 2 & 63 & 55 & 14 & 3.59 & Important \\
$\begin{array}{l}\text { You select Islamic banks because of } \\
\text { wide range of branches }\end{array}$ & 70 & 59 & 6 & 0 & 0 & 1.53 & Less Important \\
$\begin{array}{l}\text { You select Islamic banks because of } \\
\text { external appearance of the bank }\end{array}$ & 0 & 16 & 84 & 34 & 1 & 3.15 & $\begin{array}{l}\text { Moderately } \\
\text { Important }\end{array}$ \\
$\begin{array}{l}\text { You select Islamic banks because of } \\
\text { wide ATM availability }\end{array}$ & 2 & 23 & 74 & 31 & 5 & 3.10 & $\begin{array}{l}\text { Moderately } \\
\text { Important }\end{array}$ \\
\hline
\end{tabular}

Overall Weighted Average: 3.19 (Moderately Important)

Meanwhile, "convenient branch location" is categorised as "Moderately important", with an average score of 3.28 , followed by "external appearance of the bank" with an average score of 3.15 and "wide ATM availability" with an average score of 3.10. Both external appearance and wide ATM availability are regarded as "Moderately important". Finally, "wide range of branches", with an average score of 1.53 , is the least important factor in this category with verbal interpretation of "Less important". Although the overall result indicates that convenience is not as important as religious and service quality factors, it does not mean the factors under this category are to be ignored. In fact, 2 factors under these categories regarded as important selection criteria by Islamic bank customers.

The overall findings for this category are not in line with some previous studies that consider this category as important selection criteria of Islamic banks (Metawa and Al-Mossawi, 1998; Khan et al, 2007; Farooq et al, 2010; Hidayat and Al-Bawardi, 2012). Table 3 below summarizes the respondents' responses regarding the importance of convenience factors on the selection of Islamic banks.

\section{Importance of families and friends' influence factors as the selection criteria for Islamic banks}

Table 4 shows that the overall average of the respondents' responses regarding these factors is 3.19, with a verbal interpretation of "Moderately important". In 
addition, the average responses regarding the three elements of this category have a verbal interpretation of "Moderately important". "Recommendations from friends" has the highest average score (3.31), followed by "recommendation from your family" with an average score of 3.24 , and "friend/family members working for the Islamic banks" with an average score of 3.00 .

Despite families and friends' influence factors are regarded as important selection criteria by some previous studies (Metawa and Al-Mossawi, 1998; Farooq et $\mathrm{al}, 2010$ ), this study found that Islamic bank customers in Bahrain are in the opinion that these factors are not as important as religious and service quality factors. In addition, none of the items under this category obtained verbal interpretation of "Important". Table 4 summarizes the respondents' responses regarding the importance of families and friends' influence in the selection of Islamic banks.

Table 4-Summary of Respondents' Responses on the Importance of Families and Friends' Influence Factors in the Selection of Islamic Banks ( $\mathrm{n}=135$ )

\begin{tabular}{|c|c|c|c|c|c|c|c|}
\hline Item & 1 & 2 & 3 & 4 & 5 & Mean & Interpretation \\
\hline $\begin{array}{l}\text { You select Islamic banks because of the } \\
\text { recommendation from your family }\end{array}$ & 9 & 10 & 63 & 45 & 8 & 3.24 & $\begin{array}{l}\text { Moderately } \\
\text { Important }\end{array}$ \\
\hline $\begin{array}{l}\text { You select Islamic banks because of the } \\
\text { recommendation from your friends }\end{array}$ & 9 & 10 & 60 & 42 & 14 & 3.31 & $\begin{array}{l}\text { Moderately } \\
\text { Important }\end{array}$ \\
\hline $\begin{array}{l}\text { You select Islamic banks because your } \\
\text { families or friends are working for } \\
\text { Islamic banks }\end{array}$ & 10 & 24 & 60 & 38 & 3 & 3.00 & $\begin{array}{l}\text { Moderately } \\
\text { Important }\end{array}$ \\
\hline
\end{tabular}

Overall Weighted Average: 3.19 ( Moderately Important)

\section{Importance of financial benefits factors as the selection criteria for Islamic banks}

Table 5 summarizes the respondents' responses regarding the importance of financial benefits in the selection of Islamic banks. Table 5 shows that the overall average of the respondents' responses regarding the financial benefits factors is 2.82, with a verbal interpretation of "Moderately important". "Higher rate of return on deposits" has the highest average score (3.20), followed by "low service charges" with an average score of 2.79 , and the lowest average score is for "lower profit rate on financings", with an average score of 2.49 . This finding reveals that financial benefits factors are regarded less important than religious and service quality factors by Islamic bank customers in Bahrain. It also means Islamic bank customers in Bahrain are attracted to deal with Islamic banks more because of the religious and service quality factors than financial benefits factors. 
Abdulla Hamzah Al-Hadrami: The Important Selection Criteria In Choosing Islamic Banks 175

Table 5-Summary of Respondents' Responses on the Importance of Financial Benefits Factors in the Selection of Islamic Banks ( $n=135)$

\begin{tabular}{lccccccc}
\hline \multicolumn{1}{c}{ Item } & $\mathbf{1}$ & $\mathbf{2}$ & $\mathbf{3}$ & $\mathbf{4}$ & $\mathbf{5}$ & Mean & Interpretation \\
\hline $\begin{array}{l}\text { You select Islamic banks because of } \\
\text { the low profit rate on financings }\end{array}$ & 13 & 59 & 50 & 10 & 3 & 2.49 & Less Important \\
$\begin{array}{l}\text { You select Islamic banks because of } \\
\text { low service charges }\end{array}$ & 3 & 52 & 57 & 17 & 6 & 2.79 & $\begin{array}{l}\text { Moderately } \\
\text { Important }\end{array}$ \\
$\begin{array}{l}\text { You select Islamic banks because of } \\
\text { high rate of return on deposits }\end{array}$ & 1 & 11 & 90 & 26 & 7 & 3.20 & $\begin{array}{l}\text { Moderately } \\
\text { Important }\end{array}$ \\
\hline
\end{tabular}

Overall Weighted Average: 2.82 ( Moderately Important)

The finding is not in line with some previous studies that found these factors as important selection criteria of Islamic banks (Metawa and Al-Mossawi, 1998; Khan et al, 2007; Ranjbar and Sharif, 2008; Hidayat and Al-Bawardi, 2012).

\section{Testing for significant differences in the opinions by demographic profile}

The current study employed analysis of variance (ANOVA) at a 90\% level of confidence to test for any significant influence of demographic variables on the selection criteria discussed above. ANOVA was conducted to identify any statistical significance in the differences between sample elements' responses when they are grouped based on their gender, age, level of education and level of income. Table 6 summarizes the ANOVA outputs when the respondents are grouped according to their gender.

It can be concluded that the only significant difference was found for the convenience factor, which female respondents perceived to be significantly more important in selecting Islamic banks than did male customers, with average scores of 3.11 and 2.97 for female and male customers respectively. It means that female customers significantly care about convenience factors than male customers do as their selection criteria. This finding is consistent with the finding of Bhatti et.al. (2010) who found a significant relationship between the Bank's location and gender. As seen in Table 6, male customers have higher average scores than female customers in terms of the perceived importance of the religious factors in selecting Islamic banks, with an average score of 4.0877 for males and 3.9613 for females. In terms of service quality, it has been found that male customers perceived the importance of these factors in selecting Islamic banks as more important than did females (with mean scores of 3.6822 and 3.6435 respectively). Additionally, the ANOVA results show that female customers perceived the importance of the influence of family and 
friends in selecting Islamic banks as being greater than did male customers, with mean scores of 3.2355 and 3.1466 respectively. Finally, in terms of the financial benefits, the results indicated that male customers perceived the factors to be more important than did females (with mean scores of 2.8781 and 2.7710 respectively).

Table 6-Summary of ANOVA outputs when the respondents are grouped according to their gender

\begin{tabular}{cccccccc}
\hline & & & & & \multicolumn{2}{c}{ F Test } \\
& & N & Mean & Std. Deviation & F-ratio & F Sig \\
\hline \multirow{2}{*}{ Religious Factors } & Male & 73 & 4.0877 & 1.09772 & .437 & .510 \\
& Female & 62 & 3.9613 & 1.11669 & & \\
Service Quality & Male & 73 & 3.6822 & .56651 & & .178 & .674 \\
& Female & 62 & 3.6435 & .48574 & & \\
Convenience & Male & 73 & 2.9781 & .28831 & & \\
Families and Friends' & Female & 62 & 3.1129 & .27310 & & \\
Influence & Male & 73 & 3.1466 & .68294 & .596 & .441 \\
& Female & 62 & 3.2355 & .64506 & .598 & \\
Financial Benefits & Male & 73 & 2.8781 & .44853 & & \\
& Female & 62 & 2.7710 & .44662 & & \\
\hline
\end{tabular}

${ }^{*} \mathrm{P}<0.10$

When the respondents are grouped according to their age, ANOVA outputs reveal that the only significant difference was found for the religious factors, which was perceived to be significantly more important in selecting Islamic banks than other elements by respondents aged below 25, with an average score of 4.51, while respondents aged 25-35 years, 35-45 years, and more than 45 years had average scores of 4.22, 4.17, and 3.72 respectively. One possible reason is due to exposure of these age groups to Islamic finance courses at their universities. This finding is consistent with the findings of each of Bhatti et.al. (2010) and Farooq et al. (2010) who found a significant relationship between age and the religious factor.

Table 7 summarizes the ANOVA output when the respondents are grouped according to their age. As seen in Table 7 , in terms of average scores of other factors, respondents below 25 years gave an average score of 3.71 in terms of service quality, while those who were older than 45 years had an average score of 3.10 in terms of convenience. With regard to family and friends' influence, respondents who were older than 45 years had the highest average score (3.25), and finally in terms of 
financial benefits, the results revealed that respondents aged 25-35 years had the highest average score of 2.91. However, none of them are statistically significant.

When the respondents are grouped according to their level of education, ANOVA outputs reveal that the only significant difference was found for the influence of family and friends, for which the influence is significantly high for those with below high school and postgraduate degree, with an average score of 4 . This finding confirms the results of each of Metawa and Al-Mossawi (1998) and Bhatti et.al. (2010) who found a significant relationship between the education level of the respondent and the family and friends recommendation in selecting banks.

Table 7-Summary of ANOVA outputs when the respondents are grouped according to their age

\begin{tabular}{|c|c|c|c|c|c|c|}
\hline & & \multirow{2}{*}{$\mathbf{N}$} & \multirow{2}{*}{ Mean } & \multirow{2}{*}{ Std. Deviation } & \multicolumn{2}{|c|}{ F Test } \\
\hline & & & & & F-ratio & F Sig \\
\hline \multirow{4}{*}{ Religious Factors } & $<25$ & 6 & 4.5167 & .54191 & \multirow{4}{*}{2.517} & \multirow{4}{*}{$.061^{*}$} \\
\hline & $25-35$ & 43 & 4.2279 & .98617 & & \\
\hline & $35-45$ & 33 & 4.1788 & 1.00771 & & \\
\hline & $>45$ & 53 & 3.7208 & 1.23761 & & \\
\hline \multirow{4}{*}{ Service Quality } & $<25$ & 6 & 3.7167 & .56006 & \multirow{4}{*}{.204} & \multirow{4}{*}{.893} \\
\hline & $25-35$ & 43 & 3.6302 & .48133 & & \\
\hline & $35-45$ & 33 & 3.6364 & .67630 & & \\
\hline & $>45$ & 53 & 3.7038 & .46903 & & \\
\hline \multirow{4}{*}{ Convenience } & $<25$ & 6 & 3.0167 & .37103 & \multirow{4}{*}{1.384} & \multirow{4}{*}{.251} \\
\hline & $25-35$ & 43 & 2.9907 & .29424 & & \\
\hline & $35-45$ & 33 & 3.0091 & .28871 & & \\
\hline & $>45$ & 53 & 3.1019 & .27068 & & \\
\hline \multirow{4}{*}{$\begin{array}{l}\text { Families and Friends' } \\
\text { Influence }\end{array}$} & $<25$ & 6 & 2.9500 & 1.04451 & \multirow{4}{*}{.488} & \multirow{4}{*}{.691} \\
\hline & $25-35$ & 43 & 3.1721 & .65840 & & \\
\hline & $35-45$ & 33 & 3.1424 & .76650 & & \\
\hline & $>45$ & 53 & 3.2547 & .55663 & & \\
\hline \multirow{4}{*}{ Financial Benefits } & $<25$ & 6 & 2.9000 & .55136 & \multirow{4}{*}{1.102} & \multirow{4}{*}{.351} \\
\hline & $25-35$ & 43 & 2.9163 & .46236 & & \\
\hline & $35-45$ & 33 & 2.7364 & .37899 & & \\
\hline & $>45$ & 53 & 2.8075 & .46569 & & \\
\hline
\end{tabular}

${ }^{*} \mathrm{P}<0.10$ 
Table 8-Summary of ANOVA outputs when the respondents are grouped according to their level of education

\begin{tabular}{|c|c|c|c|c|c|c|}
\hline & & \multirow[t]{2}{*}{$\mathbf{N}$} & \multirow[t]{2}{*}{ Mean } & \multirow{2}{*}{$\begin{array}{c}\text { Std. } \\
\text { Deviation }\end{array}$} & \multicolumn{2}{|c|}{ F Test } \\
\hline & & & & & F-ratio & F Sig \\
\hline \multirow[t]{4}{*}{ Religious Factors } & Below High School & 1 & 4.7000 & & 1.707 & .169 \\
\hline & High School & 13 & 3.5083 & 1.23984 & & \\
\hline & Bachelor Degree & 119 & 4.0966 & 1.06643 & & \\
\hline & Postgraduate Degree & 3 & 3.2333 & 1.74738 & & \\
\hline \multirow[t]{4}{*}{ Service Quality } & Below High School & 1 & 3.7000 & & .450 & .718 \\
\hline & High School & 12 & 3.7083 & .40330 & & \\
\hline & Bachelor Degree & 119 & 3.6513 & .53991 & & \\
\hline & Postgraduate Degree & 3 & 4.0000 & .70000 & & \\
\hline \multirow[t]{4}{*}{ Convenience } & Below High School & 1 & 3.0000 & & .056 & .983 \\
\hline & High School & 12 & 3.0500 & .33166 & & \\
\hline & Bachelor Degree & 119 & 3.0378 & .28789 & & \\
\hline & Postgraduate Degree & 3 & 3.1000 & .26458 & & \\
\hline \multirow{4}{*}{$\begin{array}{l}\text { Families and Friends' } \\
\text { Influence }\end{array}$} & Below High School & 1 & 4.0000 & & 2.186 & $.093^{*}$ \\
\hline & High School & 12 & 3.0750 & .76053 & & \\
\hline & Bachelor Degree & 119 & 3.1714 & .65122 & & \\
\hline & Postgraduate Degree & 3 & 4.0000 & 0.00000 & & \\
\hline \multirow[t]{4}{*}{ Financial Benefits } & Below High School & 1 & 2.7000 & & .727 & .537 \\
\hline & High School & 12 & 3.0083 & .44611 & & \\
\hline & Bachelor Degree & 119 & 2.8134 & .45003 & & \\
\hline & Postgraduate Degree & 3 & 2.7667 & .50332 & & \\
\hline
\end{tabular}

$* \mathrm{P}<0.1$ 
As seen in Table 8, religious factors are more important for Islamic bank customers with low level of education than those with higher education as reflected by the highest score obtained by the respondent with no high school (4.7). In terms of service quality, respondents with postgraduate degree had the highest average score (4.00). It means those with high education tend to care more about service quality factors than others. However, the difference is not statistically significant. With regards to convenience, respondents with post graduate degree obtained the highest score (3.1). It means those with high education tend to care more about convenience factors than others. However, the difference is not statistically significant. Finally, in terms of financial benefits, the result shows that respondents with high school degree have the highest average score (3.00). Table 8 summarizes the ANOVA output when the respondents are grouped according to their level of education.

When the respondents are grouped according to their level of income, ANOVA outputs reveal that there are significant differences in each of religious, service quality, and financial benefits factors. Respondents in the higher income bracket (901-1400) cited religious factors as the most important element with an average score of 4.48. This finding is consistent with the finding of Metawaa and Al-Mossawi (1998) who found a significant relationship between the respondents' income and the religious factor. Additionally, as seen in Table 9 those with income more than 1400 gave an average score of 4.31 for service quality. It means as higher the income as more the requirements for service quality. For financial benefits, respondents with income less than 450 gave the highest average score of 3.05 which indicates as less the income as more interest in the financial benefits they can get from the bank. Finally, as it can be seen in Table 9, in terms of other factors, respondents with income between 450 and 900 gave the highest average score for convenience (3.04), and for family and friends' influence, those with income greater than 1400 income gave an average score of 3.42. Table 9 summarizes the ANOVA output when the respondents are grouped according to their level of income.

Table 10 shows the rank of the five factors in terms of their importance according to the respondents' opinions. As it can be seen in the Table 10, religious factors are ranked as the most important selection criteria for Islamic banks, with an overall average score of 4.02, thus Islamic banks should not follow and imitate the conventional banks without taking into consideration Sharia principles and objectives. This factor is followed by service quality, with an overall average score of 3.66, therefore, Islamic banks must pay more attention to this factor by acquiring up-to-date devices in order to improve the quality and efficiency of the services provided. In the third rank come the convenience factors with an overall average 
score of 3.19. This means that the Islamic banks must give more attention to the internal and external interiors to make them more attractive. In the fourth rank comes the importance of families and friends' influence also with overall average scores of 3.19. However, it is ranked fourth since no factor under this category obtained average scores with verbal interpretation of "Important". In the last rank come financial benefits, with an overall average score of 2.82 .

Table 9-Summary of ANOVA outputs when grouped according to their level of income

\begin{tabular}{|c|c|c|c|c|c|c|}
\hline & & \multirow{2}{*}{$\mathbf{N}$} & \multirow{2}{*}{ Mean } & \multirow{2}{*}{ Std. Deviation } & \multicolumn{2}{|c|}{ F Test } \\
\hline & & & & & F-ratio & F Sig \\
\hline \multirow{4}{*}{ Religious Factors } & $<450$ & 6 & 4.1667 & .95847 & \multirow{4}{*}{2.731} & \multirow{4}{*}{$.032^{* *}$} \\
\hline & $450-900$ & 81 & 3.8160 & 1.20296 & & \\
\hline & $901-1400$ & 39 & 4.4821 & .57394 & & \\
\hline & $>1400$ & 9 & 3.8000 & 1.59553 & & \\
\hline \multirow{4}{*}{ Service Quality } & $<450$ & 6 & 3.3333 & .31411 & \multirow{4}{*}{4.484} & \multirow{4}{*}{$.002^{* *}$} \\
\hline & $450-900$ & 81 & 3.6383 & .52382 & & \\
\hline & $901-1400$ & 39 & 3.6205 & .48946 & & \\
\hline & $>1400$ & 9 & 4.3125 & .45493 & & \\
\hline \multirow{4}{*}{ Convenience } & $<450$ & 6 & 2.9833 & .42151 & \multirow{4}{*}{.167} & \multirow{4}{*}{.955} \\
\hline & $450-900$ & 81 & 3.0469 & .28900 & & \\
\hline & $901-1400$ & 39 & 3.0462 & .29096 & & \\
\hline & $>1400$ & 9 & 3.0000 & .20702 & & \\
\hline \multirow{4}{*}{$\begin{array}{l}\text { Families and Friends' } \\
\text { Influence }\end{array}$} & $<450$ & 6 & 2.8833 & .97656 & \multirow{4}{*}{.973} & \multirow{4}{*}{.425} \\
\hline & $450-900$ & 81 & 3.2346 & .69267 & & \\
\hline & $901-1400$ & 39 & 3.1000 & .51401 & & \\
\hline & $>1400$ & 9 & 3.4250 & .78513 & & \\
\hline \multirow{4}{*}{ Financial Benefits } & $<450$ & 6 & 3.0500 & .49699 & \multirow{4}{*}{2.126} & \multirow{4}{*}{$.081^{*}$} \\
\hline & $450-900$ & 81 & 2.7975 & .41139 & & \\
\hline & $901-1400$ & 39 & 2.9308 & .50947 & & \\
\hline & $>1400$ & 9 & 2.5000 & .32514 & & \\
\hline
\end{tabular}

$* \mathrm{P}<0.1 * * \mathrm{P}<0.05$ 
The descriptive statistics shows that the overall average scores for religious factors and service quality factors are categorized as "Important". This finding is in line with findings of Metawa and Al-Mossawi (1998) and Khan et al. (2007), Hague et al. (2009), Bhatti et.al (2010), Farooq et al. (2010), Abduh and Omar (2012), and Usman (2015). Therefore, these are the two most important selection criteria of Islamic banks according to Islamic bank customers in Bahrain. In addition, two factors of convenience namely comfort interior and available parking space are also regarded as important selection criteria, which are not identified by Metawa and Al-Mossawi (1998). This is probably due to the new development in the banking industry between 1998 and 2015 where competition among the banks is tougher than before which requires Banks to pay attention into those factors. In addition, the life style of the people in Bahrain and the Gulf countries in general has changed to more luxurious style.

Table 10. Factors rank according to the respondents' responses

\begin{tabular}{|c|c|c|}
\hline Rank & Factor & Overall Average (OA) \\
\hline 1 & Religious factors & 4.02 \\
\hline 2 & Service quality & 3.66 \\
\hline 3 & Convenience & 3.19 \\
\hline 4 & Families and friend's influence & 3.19 \\
\hline 5 & Financial benefits & 2.82 \\
\hline
\end{tabular}

Several analyses of variance (ANOVA) were conducted to determine the impact of the demographic variables (gender, age, level of education, and level of income) on the study factors (religious, service quality, families and friends' influence, convenience, and financial benefits). Table 11 summarizes the ANOVA results.

Table 11-Summary of the ANOVA test results

\begin{tabular}{cc}
\hline Demographic Variables & Significant differences among respondents \\
\hline Gender & Convenience factors \\
Age & Religious factors \\
Level of education & Families and friends' influence factors \\
Level of income & Religious, Service Quality and Financial benefits factors \\
\hline
\end{tabular}




\section{Conclusion}

The findings of this study have met the objectives of the study. The most important factors that influence the decision of customers when they select Islamic banks have been identified. The findings reveal that when the respondents are grouped according to their gender, the only significant difference among respondents is for the convenience factors, and when the respondent are grouped according to their age, the only significant difference among respondents is for the religious factors. Moreover, when the respondent are grouped according to their level of education, the only significant difference among respondents is for families and friends' influence, and when the respondent are grouped according to their level of income, there were significant differences among respondents for religious, service quality, and financial benefits factors.

Based on its findings, the study also comes out with the following recommendations: First, the customer relations department should seek to improve customer relationship by considering the most important selection criteria of Islamic banks namely religious and service quality factors. Second, special care should be taken to ensure that bank branches are conveniently located, that their interior is comfortable and that there is parking available, as these are also considered to be important factors. Third, human resource departments should perform continuous training programs to maintain "fast, efficient, accurate and high quality" services, as they are considered to be important selection criteria.

Finally, like any other studies, this study has its limitations, which can be filled by future studies. Among them are: First, there are other factors that have not been examined in this study that might affect customer selection criteria of Islamic banks such as mass media advertising, staff, and the bank's size and reputation factors. Second, the sample size of study is small: a larger sample size would lead to more accurate results. Third, the research respondents were predominantly individuals with university and higher education, and the sample size for lower educated respondents was small. Including more lower-educated customers might influence selection criteria. Fourth, the research respondents were individual dealers with Islamic banks, including the corporate dealers might reveal different results. Fifth, the study used the descriptive analysis to analyze the collected data. Using other technique such as regression analysis might add value to the result. Sixth, the current study did not use the qualitative approach such as interviews to collect the research data. Using such technique will help in exploring other factors not discussed previously. And so might add more accuracy to the data collected. 


\section{References}

Abduh, M., \& M.A. Omar. (2012). Islamic Bank selection criteria in Malaysia: An AHP Approach. Business Intelligence Journal, 5(2): 217-281.

Al-Hadrami, A. \& S. Hidayat. (2015). Obstacles to Integrating Forensic Accounting in the Accounting Curriculum: The Case of Bahrain. Global Review of Accounting and Finance, 6(1): 165-175.

Ali, S. S. (2011). Islamic Banking in the MENA Region,. Jeddah: The World Bank and Islamic Development Bank-Islamic Research and Training Institute.

Bhatti, G. et.al. (2010). Determinants of Customer Satisfaction and Bank Selection in Pakistan. Interdisciplinary Journal of Contemporary Research in Business, 2(6): 536-544.

Dusuki, A., \& N. Abdullah. (2006). Why do Malaysian Customers Patronize Islamic Banks? International Journal of Bank Marketing, 25(3): 142-160.

Farooq, U. et.al. (2010). Profile Analysis of the Customers of Islamic Banking in Peshawar, Pukhtunkhwa. International Journal of Business and Management, 5(11): 106-117.

Gait, A. \& A. Worthington. (2007). An Empirical Survey of Individual Consumer, Business Firm and Financial Institution Attitudes towards Islamic Methods. Working Paper. School of Accounting and Finance, University of Wollongong. Hague, A. et.al. (2009). Factor Influences Selection of Islamic Banking: A Study on Malaysian Customer Preferences. American Journal of Applied Sciences, 6 (5): 922-928.

Hair, J. et.al. (2010) Multivariate data analysis. 7th ed, Englewood Cliffs: Prentice Hall.

Hidayat, S. E. (2010). Islamic Finance: The Original Wisdom Behind its Establishment. Islamic Finance News, 7(31): 23-30.

Hidayat, S. E. \& N.K. Al-Bawardi. (2012). Non Muslims' Perceptions Toward Islamic Banking Services in Saudi Arabia. Journal of US-China Public Administration, 9 (6): 654-670.

Hidayat S. \& A. Al-Hadrami. (2015). Forensic Accounting Education in Bahrain: A survey on Educators' Opinion. International Journal of Pedagogical Innovations, 3 (1): 7-16.

Izhar, H. \& Y. Rehman. (2014). Global Islamic Finance Outlook 2014. Islamic Finance News, 11(3): 25-26.

Khan, M. et.al. (2007). Banking Behavior of Islamic Bank Customers in Bangladesh. Journal of Islamic Economics, Banking and Finance, 3(2): 159-194. 
Metawa, S. \& M. Al-Mossawi. (1998). Banking Behavior of Islamic Bank Customers: Perspectives and Implications. International Journal of Bank Marketing, 6(5): 299-313.

Mullineux, A. \& V. Murinde. (2003). Handbook of International Banking. Cheltenham, UK and Northampton, USA: Edward Elgar.

Ranjbar, A. \& S. Sharif. (2008). Islamic Banking Selection Criteria: An Empirical Study in Malaysia. Kuala Lumpur: SSRN.com, 1898663.

Usman, H. (2015). The Role of Religious Norms on Selecting The Islamic Bank. Al-Iqtishad: Jurnal Ilmu Ekonomi Syariah (Journal of Islamic Economics),. Vol. VII (1): 31-44 